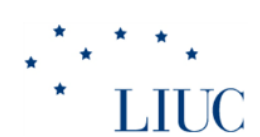

The European Journal of Comparative Economics

Vol. 15, n. 1, pp. 3-9

ISSN 1824-2979

\title{
Human Capital in the Twenty First Century
}

\author{
Daniel Kuehn ${ }^{1}$
}

\begin{abstract}
This paper reviews Thomas Piketty's treatment of human capital in Capital in the Twenty First Century. It first explores Piketty's reasons for excluding human capital from the analysis, and determines that the fact that human capital is not sold on a market is not a sufficient argument for exclusion. The "fundamental laws of capitalism" do not rely on the assumption that capital is exchanged on a market. The paper further argues that Goldin and Katz's (2008) work on education and income inequality is more compatible with Capital in the Twenty First Century than many critics suggest. The paper concludes by arguing that including human capital in the broader discussion of inequality should not detract from Piketty's broader findings.
\end{abstract}

JEL codes: I24, J24, N32, and O41

Keywords: human capital, inequality, wealth

\footnotetext{
"Capital is not an immutable concept: it reflects the state of development and prevailing social relations of each society." (Piketty, 2014; p. 47)
}

\section{Introduction}

Mankiw, Romer, and Weil's (1992) seminal paper on growth empirics memorably begins with "this paper takes Robert Solow seriously". In a similar way, this paper takes Thomas Piketty seriously. Mankiw, Romer, and Weil argued that Solow's (1956) simple growth model maintained relevance in the decades following its publication, but that it could be improved (particularly in empirical applications) by including human capital. This paper makes precisely the same claim about Piketty's Capital in the Twenty First Century. He has made a valuable contribution to the economics of inequality, but the contribution would be strengthened by more serious consideration of the role of human capital in income and wealth inequality.

After briefly reviewing the significance of the human capital stock, this paper will offer three claims related to Piketty's book: First, that contrary to Piketty's view, the alienability of capital is not a requirement for the consideration of a species of capital in an analysis of capital or the fundamental laws of capitalism. Second, that Goldin and Katz's (2008) work on education is more compatible with Piketty's (2014) thesis than many critics of Piketty suggest. Third, that the tremendous importance of human capital offers no necessary guard against the unequal distribution of financial and physical capital discussed by Piketty.

\footnotetext{
${ }^{1}$ Daniel Kuehn is a Research Associate I in the Urban Institute's Income and Benefits Policy Center
} 
Estimation of the human capital stock is imprecise compared to estimation of the physical and financial capital stock, because human capital is not sold in a market (a difference imbued with considerable significance by Piketty that will be discussed in more detail below). Human capital values are typically estimated by taking the present value of a stream of future earnings, which the marginal worker sets equal to the costs of acquiring human capital. Various assumptions are used to allocate total future earnings between human capital and raw labor. This approach is conceptually similar to the capitalization method used by Saez and Zucman (2016) to estimate the physical and financial capital stock.

All estimates suggest that the stock of human capital in the modern economy is enormous. Jones and Fender (2011) find that the United Kingdom's human capital stock is two and a half times the total value of the country's tangible assets in 2010. This is smaller than estimates produced by Liu (2011) for a number of OECD countries, which range between three and seven times the value of physical capital. Christian (2010) produces an even larger estimate of the human capital stock in the United States, roughly sixteen times the stock of fixed assets and consumer durables. This range of estimates illustrates the enormity of the human capital stock as well as the inherent difficulties in measuring it.

Piketty, to his credit, accepts the significance of the human capital stock. He calls such large estimates "perfectly obvious," noting "whenever more than half of national income goes to labor and one chooses to capitalize the flow of labor income at the same or nearly the same rate as the flow of income to capital, then by definition the value of human capital is greater than the value of all other forms of capital" (Piketty, 2014; p. 163). ${ }^{2}$ Nevertheless, Piketty is adamant that it is inappropriate to consider human capital in his analysis of capital in the twenty first century. He takes a surprisingly strong (and brief) stance against the consideration of human capital in the book. Piketty writes that "attributing a monetary value to the stock of human capital makes sense only in societies where it is actually possible to own other individuals fully and entirely societies that at first sight have definitely ceased to exist" (Piketty, 2014; 163). This decision is closely tied to the standard approach for measuring the physical and financial capital stock, using actual or estimated market values. Without a market for trading human capital, Piketty considers this particular type of capital inadmissible in the analysis.

\section{Human capital and Piketty's fundamental laws}

When Piketty asserts that discussion of human capital in the context of his book only makes sense when humans can be owned "fully and entirely" he is demanding that

\footnotetext{
${ }^{2}$ Of course a portion of the value generated by human capital accrues to the employer, and a portion to the worker. Following Becker (1964), most economists agree that the employer is able to capture the benefits of (and therefore more willing to pay for) specific human capital. However, market imperfections may also allow them to enjoy the benefits of general human capital (see for example Acemoglu and Pischke, 1999).
} 
human capital exhibit the property of alienability: the potential for an owner to sell a piece of property to a new owner. It is not clear at all that Piketty's concerns about the alienation of human capital have any relevance to his "fundamental laws of capitalism" or the dynamics of capital.

The fundamental laws are of course familiar in the literature on economic growth. The first law $(\alpha=\mathrm{r} \beta)$ is a definition and the second $(\beta=\mathrm{s} / \mathrm{g})$ is an equilibrium condition dating back to the founding papers of the modern growth literature. The first law requires only that a piece of capital earn a return, $r$, for the capital share of income, $\alpha$, to be determined by the product of $\mathrm{r}$ and the capital stock as a share of income, $\beta$. This definition is true for capital as a whole and for any conceivable sub-component of capital and it is fundamental to the capitalization method discussed above. It therefore requires no further discussion for the case of human capital. Piketty unambiguously acknowledges that the stock of human capital can be derived from information on its rate of return and its share of income (Piketty, 2014; p. 163).

The second law is a somewhat more difficult case, although the lack of dependence on the alienability of capital can be easily demonstrated by considering a few workhorse growth models. Piketty's second fundamental law is the classic HarrodDomar-Solow equation:

$\beta=\mathrm{s} / \mathrm{g}$

where $\beta$ is the ratio of capital to total income, $s$ is the savings rate, and $g$ is the growth rate of the economy. Capital accumulation occurs by withholding income from consumption to purchase capital, and the relative prominence of capital $(\beta)$ is determined by the balance between capital accumulation and the growth of the economy. In the Solow model, and apparently in Piketty (2014), there is no endogenous determination of s. Capital accumulation is determined by given parameters rather than optimizing behavior and a set of "deep parameters".

In the Ramsey-Cass-Koopmans model, in contrast, saving and consumption behavior is determined by an optimization process. The capital dynamics in this model lead to the same fundamental equation of $\beta=\mathrm{s} / \mathrm{g}$. Instead of being given a savings rate, $\mathrm{s}$, savings are calculated using the optimizing behavior of consumers. The consumption dynamics in the model pin optimal capital per worker, $k^{*}$, down with the Euler equation, so that $\mathrm{k}^{*}$ satisfies $\mathrm{f}\left(\mathrm{k}^{*}\right)=\varrho-\theta \mathrm{g}$, where the marginal product appears on the left hand side of the equation, and the right hand side is the discount rate, $\varrho$, minus the risk aversion parameter $\theta$ times productivity growth, $g$. With $\mathrm{k}^{*}$ determined, $\mathrm{c}^{*}$ can be solved for by plugging $\mathrm{k}^{*}$ into the capital dynamics equation. $\mathrm{k}^{*}$ and $\mathrm{c}^{*}$ together determine total savings as $f\left(k^{*}\right)-c^{*}$. Then the capital dynamics are:

$\mathrm{dk}=\mathrm{f}\left(\mathrm{k}^{*}\right)-\mathrm{c}^{*}-(\mathrm{n}+\mathrm{g}) \mathrm{k}^{*}$ 
In equilibrium $\mathrm{dk}=0$, so

$f\left(k^{*}\right)-c^{*}=\operatorname{sf}\left(k^{*}\right)=(n+g) k^{*}$

The Ramsey-Cass-Koopmans model is typically expressed in per capita terms, but can easily be rearranged to show the capital stock relative to income $(\beta)$,

$\operatorname{sf}\left(\mathrm{k}^{*}\right)=(\mathrm{n}+\mathrm{g}) \mathrm{k}^{*} \rightarrow \mathrm{s} /(\mathrm{n}+\mathrm{g})=\mathrm{k}^{*} / \mathrm{f}\left(\mathrm{k}^{*}\right)$

Multiplying the numerator and the denominator by the population, it becomes clear that the per-capita Ramsey-Cass-Koopmans terms are the same as Piketty's relations:

$\mathrm{s} /(\mathrm{n}+\mathrm{g})=\mathrm{k}^{*} / \mathrm{f}\left(\mathrm{k}^{*}\right)=\mathrm{K}^{*} / \mathrm{F}\left(\mathrm{K}^{*}\right)=\beta$

Unlike Piketty's $\beta=\mathrm{s} / \mathrm{g}$, the denominator of the left hand side of equation (5.) is $(n+g)$. However, for Piketty, $g$ is nominal income growth which is equal to labor force growth plus real productivity growth, or $(\mathrm{n}+\mathrm{g})$.

The critical point is that optimization in the Ramsey-Cass-Koopmans model, which remedies the Solow model's ad hoc determination of savings, relies on a capital market where capital can be alienated. The capital market enters the model through the consumer's budget constraint, and the interest rate is determined by equilibrium in the capital market. The irony here is that the model most closely associated with Piketty's "fundamental laws," the Solow model, is not dependent at all on the property of alienability. There is no sale of capital to firms. Instead, the same centralized agent makes exogenous savings decisions, thereby accumulating capital that is used in production but never itself sold on a market. The Ramsey-Cass-Koopmans model incorporates alienability by introducing a capital market. But here the "fundamental laws" are no different than in the original Solow model. The obvious conclusion is that the alienability of capital has nothing whatsoever to do with Piketty's analytic framework and therefore cannot disqualify human capital from consideration. If alienability is not a requirement, then Piketty's argument against considering human capital fails.

If Piketty were to fully integrate human capital into his analysis the greatest problems would not be posed by the limited alienability of human capital in a market. Instead, the greatest challenges would be introduced by the human capital accumulation process itself. Some human capital is accumulated in the same way that physical or financial capital is accumulated: through the expenditure of savings on capital goods (e.g., education). Incorporation of this sort of human capital accumulation would simply require a reclassification of expenditures on education as investments. Human capital acquired on the job, however, does not require the accumulation of monetary savings, although it may have costs in terms of time or effort. These budget constraints are not 
typically specified in growth models and would affect the fundamental laws more directly than capital alienability. In principle the second fundamental law would remain the same; the capital ratio would still be determined by a balancing between the capital accumulation process and the growth of the economy. The exact specification of capital accumulation, however, would be more complicated. Parsimony may dictate the exclusion of these sorts of human capital accumulation processes from Piketty's narrative, but the inalienability of human capital is clearly not the strong defense of excluding human capital itself that Piketty makes it out to be.

\section{Human capital and inequality}

Goldin and Katz (2008) have, for better or worse, become a focal point for discussions of the relationship between human capital and trends in inequality. Goldin and Katz's (2008) argument that fluctuations in the supply of human capital are an important determinant of income inequality have been repeatedly juxtaposed with Piketty's (2014) claim that the labor income of "super-managers," inheritance, and the capital income of the wealthiest one percent are the most important. To a considerable extent the clash with Goldin and Katz is artificial. Goldin and Katz demonstrate the importance of the college wage premium for broader measures of inequality such as the Gini coefficient, which is largely independent of Piketty's concern with the very wealthiest members of society. Piketty himself argues that these are distinct phenomena, although he notes that even using broader measures (such as the top decile's share of national income), the performance of the one percent overshadows the role of human capital:

"In short, two distinct phenomena have been at work in recent decades. First, the wage gap between college graduates and those who go no further than high school has increased, as Goldin and Katz showed. In addition, the top 1 percent (and even more the top 0.1 percent) have seen their remuneration take off. This is a very specific phenomenon, which occurs within the group of college graduates and in many cases separates individuals who have pursued their studies at elite universities for many years. Quantitatively, the second phenomenon is more important than the first. In particular, as shown in the previous chapter, the overperformance of the top centile explains most (nearly three-quarters) of the increase in the top decile's share of US national income since 1970.” (Piketty, 2014; p. 315).

If anything, the contrast between Piketty on the one hand and Goldin and Katz on the other is not promoted by Piketty so much as by Piketty's critics. Mankiw (2014), critiquing Piketty from the right and Galbraith (2014), from the left, both draw a stark contrast between his work and that of Goldin and Katz - much starker than the contrast drawn by Piketty himself. Mankiw (2014) happily sides with Goldin and Katz against Piketty while Galbraith (2014) grudgingly sides with Piketty against Goldin and Katz.

If Goldin and Katz (2008) are different from but compatible with Piketty (2014), then perhaps Piketty is free to ignore the problem of human capital simply because he is not personally concerned with the broader measures of inequality relevant to Goldin and Katz's analysis. Some, such as Autor (2014) have made precisely this distinction and suggested that the Goldin and Katz (2008) argument about the college earnings 
premium and technology is not relevant to Piketty's narrative about the wealthiest one percent, but that it is important to explaining inequality within the lower ninety-nine percent.

Unfortunately, this understates the importance of human capital for Piketty's own narrative about capitalism's tendency towards inequality. While human capital itself cannot be bought and sold like a unit of physical capital (the alienability point, discussed above), it clearly earns a return (recorded as wage income in national income statistics) which is typically spent or reinvested in physical or financial capital rather than additional human capital. College educated workers do not save so that they can engage in further human capital accumulation (e.g., go back to college). Instead they invest in the more traditional forms of capital with which Piketty is concerned. That capital is both alienable and heritable. Piketty discusses the accumulation of housing capital in particular by the middle class in the middle of the twentieth century as an essential feature of the long-term trends in wealth inequality. Insofar as broad growth in human capital has been a driver of the accumulation of housing wealth, the Goldin and Katz (2008) work is directly relevant to Capital in the Twenty-First Century. Although middle class capital accumulation is dwarfed by the holdings of super-wealthy, the logic of inheritance and $r>g$ apply just as surely to the "patrimonial" middle classes as the upper class. Human capital is significant, then, because it plants the seeds of broader capital holdings.

\section{Conclusions}

This brief review of Piketty's treatment of human capital takes the enormity of the human capital stock as given and considers the case for excluding this class of capital from Capital in the Twenty-First Century. Piketty's argument that human capital can be safely ignored because it is not alienable is wrong. The book's discussion of capital and capital dynamics is framed by two "fundamental laws," which are really just familiar components of standard growth models. Critically, neither of these fundamental laws depend on the alienability of capital; they hold true in models with and without alienability. There is therefore no reason to demand alienability in the discussion of capital provided by Piketty.

The only sensible reason to exclude human capital is for subject matter considerations. Human capital is different from physical and financial capital, and Piketty is interested only in the latter. On its face, this argument is entirely legitimate. No author is obligated to be interested in all subjects of study. It becomes a problem, however, when predictions about the course of capital and inequality omit a major component of the national capital stock. Human capital is clearly the single most important species of capital in modern economies, and the rise of the middle class in the twentieth century proves that it is also significant for understanding the accumulation of capital and concentration of wealth going forward. 


\section{References}

Acemoglu D., Pischke J.-S. (1999), 'Beyond Becker: Training in Imperfect Labour Markets', The Economic Journal, 109(453), F112-F142. url: http://onlinelibrary.wiley.com/doi/10.1111/1468$\underline{0297.00405 / \text { abstract }}$

Autor D. (2014), 'Skills, education, and the rise of earnings inequality among the 'other 99 percent'.', Science, 344(618), 843-851. url: http://www.sciencemag.org/content/344/6186/843.abstract

Becker G. (1964), Human Capital. National Bureau of Economic Research and Columbia University Press.

Christian M. S. (2010), 'Human Capital Accounting in the United States 1994-2006', Survey of Current Business, 90 (June 2010), 31-36. url: https://bea.gov/scb/pdf/2010/06\%20June/0610 christian.pdf

Galbraith J. K. (2014), 'Kapital for the Twenty-First Century?', Dissent. Spring, 2014. url: http://www.dissentmagazine.org/article/kapital-for-the-twenty-first-century

Goldin C, Katz L. (2008), The Race Between Education and Technology, Harvard University Press, Cambridge, MA. url: http://www.hup.harvard.edu/catalog.php?isbn=9780674035300

Jones R., Fender V. (2011), 'Human Capital Estimates, 2010', The Office for National Statistics. url: http://www.ons.gov.uk/ons/rel/wellbeing/human-capital-estimates/2010/humancapital-estimates-2010.html

Liu G. (2011), 'Measuring the Stock of Human Capital for Comparative Analysis: An Application of the Lifetime Income Approach to Selected Countries', OECD Statistics Working Papers, 2011/06, OECD Publishing. url: http://www.oecd-ilibrary.org/economics/measuringthe-stock-of-human-capital-for-comparative-analysis $5 \mathrm{~kg} 3 \mathrm{~h} 0$ jinn $9 \mathrm{r} 5$-en

Mankiw G., Romer D, Weil D. (1992), 'A Contribution to the Empirics of Economic Growth', Quarterly Journal of Economics, 107(2), 407-437. url: https://ideas.repec.org/a/tpr/qjecon/v107y1992i2p407-37.html

Mankiw G. (2014), 'Correspondence: The One Percent: Robert Solow, N. Gregory Mankiw, Richard V. Burkhauser, and Jeff Larrimore', Journal of Economic Perspectives, 28(1), 243-248. url: https://www.aeaweb.org/articles.php?doi=10.1257/jep.28.1.243

Piketty T. (2014), Capital in the Twenty-First Century, The Belknap Press of Harvard University Press, Cambridge, MA,. url: http://www.hup.harvard.edu/catalog.php?isbn=9780674430006

Saez E., Zucman G. (2016), Wealth Inequality in the United States Since 1913: Evidence from Capitalized Income Tax Data', Quarterly Journal of Economics, 131(2), 519-578. url: https://academic.oup.com/qje/article/131/2/519/2607097.

Solow R. (1956), 'A Contribution to the Theory of Economic Growth', Quarterly Journal of Economics. 70(1), 65-94. url: http:// qje.oxfordjournals.org/content/70/1/65.abstract 